\title{
EU PREFIRO SER ESSA METAMORFOSE AMBULANTE! A ORDEM DAS COISAS NO PÓS-MODERNIDADE
}

\author{
E.PEREIRA FILHO*, M.E.M.AÑEZ \\ Instituto Federal de Educação, Ciência e Tecnologia da Paraíba \\ evadio.filho@gmail.com*
}

Artigo submetido em 23/08/2018 e aceito em 28/08/2019

DOI: $10.15628 /$ holos.2019.7663

\section{RESUMO}

Apresentamos a resenha da obra:

Maffesoli, M. (2016). A ordem das coisas: pensar a pós-modernidade. Rio de Janeiro: Editora Gen.

PALAVRAS-CHAVE: Pensamento, Epistemologia, Verdades.

\section{PREFER TO BE THAT ITINERANT METAMORPHOSIS! THE ORDER OF THINGS IN THE POST-MODERNITY}

\section{ABSTRACT}

We present the work's review: Maffesoli, M. (2016). A ordem das coisas: pensar a pós-modernidade. Rio de Janeiro: Editora Gen.

KEYWORDS: Thought, Epistemology, Truths. 


\section{RESENHA}

Um dos elementos de dubiedade enfrentado por pesquisadores se refere ao posicionamento paradigmático. A conviç̧ão e escolha por uma abordagem ou outra depende do modo de pensar e ser do sujeito. Há quem opte por uma vertente que compreende a realidade sob o olhar de uma natureza objetiva, com o conhecimento adquirido e probante em termos práticos, com o ser humano e suas experiências se constituindo frutos do meio natural, além do uso de técnicas nomotéticas. Outros se inclinam para um entendimento da realidade como produto da cognição individual, anti-positivistas, o ser humano imerso em um papel mais criativo e criador do ambiente, adeptos a métodos ideográficos. À luz desse debate, Michel Maffesoli em sua obra $A$ ordem das coisas: pensar a pós-modernidade teceu uma reflexão sobre o atraso epistemológico que pode existir entre épocas distintas. Em suas primeiras linhas, o autor realçou a preocupação em apegar-se incontestavelmente a ideias antiquadas e formuladas por um clã. Argumentou que esse processo impediu o ato de desnudar a real dinâmica da vida efetiva. Convocou os leitores a se colocarem como simples poetas, pois somente assim é possível traduzir os códigos que o autêntico pensamento se reveste. O livro estrutura-se em oito capítulos, em quais se narrou as facetas do pensamento humano em eras diferentes, encorajando os sujeitos a expandir o pensamento para o método dialético capaz de alinhar pedaços antagônicos da realidade mundana.

O primeiro capítulo põe o leitor diante de faces heterogêneas do pensamento. Relatou tanto o pensamento dogmático manifestado por raízes religiosas judaico-cristãs, quanto o reordenamento e reorientação das coisas a partir dos ideais relativistas emanados pela hermenêutica. Relatos iniciais se voltam a ocidentatização do mundo, em que a sociedade moderna cultuava o Deus uno, a verdade única e intocável em sua essência. Esse conceito de verdade, como dogma, traz à tona a ideia de verdade substancial. A ciência moderna passou a ser regida por uma pulsão unificadora que conduz o espírito, a exemplo das regras do método sociológico de Émile Durkheim e da metáfora da infalibilidade pontifical. Isso fez o Ocidente vivenciar um declínio não só geopolítico, mas também epistemológico. Emergiu-se uma nova maneira de formular conhecimento, rotulado orientalização do mundo. Esse movimento despertou a partir de questionamentos da humanidade sobre a validade dos conformismos vigentes. Defendeu-se a tese de verdades múltiplas, variante em função do momento em que se situava. As verdades passaram a ser temporais. É preciso entender a forma como as verdades singulares se associavam. As verdades são aproximadas e nunca retratam a totalidade do fenômeno. Nesse diapasão, expõe a hermenêutica como fonte de libertação dos assujeitamentos a valores dogmáticos. $\mathrm{O}$ autor sublinhou esse caminho como preferível à liberdade de espírito, sendo fonte fértil do ato de conhecimento. Passou a incentivar ações refletidas, não com o propósito de edificar algo. A intenção consistia em revelar o conteúdo da realidade, em um processo dinâmico e direcionado pela razão sensível.

O segundo capítulo dissertou sobre as sagas mítica e mística que permeiam a sociedade. A primeira focou no particular, subjetivismo, strictissimo sensu. Entendia a ordem das coisas sob o 
olhar da consciência individual, da intuição originária. A organização da sociedade se moldava às experiências míticas de cunho religioso, as quais expressavam um conhecimento radical e inato aos sujeitos. Os mitos contribuíam para um reaprendizado coletivo das razões de viver. Por outro lado, a saga mística refletia a (in)consciência coletiva, constituindo o habitus societal. Essa díade conduziu ao desenho da sociologia original, cujo propósito voltou-se a junção do subjetivo com o objetivo. Essa perspectiva permitia captar e harmonizar a ordem conflituosa do "sendo" social e do "ser" societal. Recomendou o pensamento lúcido e prudente como um dos ecos para a ordem das coisas.

O terceiro capítulo descreveu o pensamento tradicional. Este se empenhava em desvendar as lições concretas e originárias que se podia extrair da história humana, e consequentemente repassá-las para gerações futuras. Contudo, a paranóia construtivista alimentou a crise do período moderno. Houve uma migração axiológica do racional para o emocional, intitulada lei de reversão. Mencionou que as progressões do pensamento, em certos momentos, recorrem a ideais antecedentes. Em outros casos, o próprio pensamento tradicional era responsável por "inventar" saberes estabelecidos. No quarto capítulo, Michel Maffesoli advogou que é preciso enxergar a realidade, mesmo que muitos não saibam ou não queiram ver. A construção do saber assemelhase a passagem da infância para a maturidade, em que não se deve prender a porquês ilusórios, mas sim buscar ao como transcorrem as coisas. Nessas construções cognitivas, é relevante rotular os objetos para se afastar da desordem do mundo. Processo em que se questionou a autonomia do sujeito em edificar o mundo a partir das suas convicções. Esse cenário sobrelevou o sujeito em um papel de mero participante e não protagonista. O autor robusteceu a ideia de razão aberta em que se contemplaram emoções e afetos coletivos. As verdades são tangenciadas no momento em que se procurar ver os fatos pela sua essência, sendo resultantes do próprio mundo. As verdades das coisas se circunscrevem no mundo natural e não em uma teia artificial. Isso leva o saber a se manifestar, a posteriori, para dar sentido à existência do eu e da coletividade.

O quinto capítulo debruçou sobre a tênue distinção entre real e realidade. Enunciou, com veemência, a necessidade dos sujeitos em ver e compreender não a realidade em si, reprimida na racionalidade e em uma única dimensão do viver-junto: cultural, político, por exemplo. Seria preciso explorar o real, em suas múltiplas faces complexas. Entender o efeito holístico e sistêmico dos vários elementos que integram o conjunto do estar-junto se constitui basilar. Esse conhecimento ordinário de um real polissêmico não é guiado tão somente pela razão pura, mas acaba por receber aportes do senso comum. Tipologia tão característica do saber coletivo, do saber comunitário, o qual foi trabalhado nos dois capítulos subsequentes. $O$ autor destacou as potencialidades do real a nível coletivo e não mais sob o foco individual, inclusive incorporando as práticas ancestrais e os imprevistos ao saber comunitário. Não é mais o "eu penso" que reina, mas o "nós pensamos" que conduz a vida pós-moderna. Esse devir que permeia e problematiza a socialidade deve ser reconhecida por todos, e exige que haja a integração dos inúmeros elementos da comunidade em seu tempo presente.

À luz dessa arguição, a obra conclui legitimando a ação de acoplar o pensamento e a paixão como panacéia. Edificou a ideia do pensamento apaixonado capaz de ampliar o que os seres humanos sabem a respeito do mundo da vida. $E$ isso não indica restringir-se a críticas contra o 
saber dominante. É válido atestar que o pensar generoso e construtivo cativou a configuração da ordem das coisas na pós-modernidade, ratificando as verdades dadas e aquelas que se ajustam a época atual.

\section{REFERÊNCIAS}

Maffesoli, M. (2016). A ordem das coisas: pensar a pós-modernidade. Rio de Janeiro: Editora Gen. 